\title{
Fe Absorption and Distribution of Imperata cylindrica (L.) P. Beauv. under Controlled Conditions
}

\author{
Alejandro Franco ${ }^{1}$, Lourdes Rufo ${ }^{1,2}$ and Vicenta de la Fuente ${ }^{1^{*}}$ \\ ${ }^{1}$ Dpto Biología, Facultad de Ciencias, Universidad Autónoma de Madrid, Cantoblanco, E-28049 Madrid, Spain \\ ${ }^{2}$ Dpto de Farmacia, Facultad de Ciencias Biosanitarias, Universidad Francisco de Vitoria, E-28223 Pozuelo de Alarcón, Madrid, Spain
}

\begin{abstract}
Background and aims: Imperata cylindrica (L.) P. Beauv. is a grass whose capacity to hyperaccumulate Fe and biomineralize jarosite has been proved in its natural habitat. Here we carried out an experiment to reproduce the Fe hyperacummulation under laboratory controlled conditions and a study to locate and identify the Fe compounds formed in the process.
\end{abstract}

Methods: The experiment was conducted with plants cultivated in a hydroponic culture in Hoagland solution enriched with $300 \mathrm{mg} / \mathrm{kg}$ of $\mathrm{Fe}$ at $\mathrm{pH} 3$ for 60 days. Samples were analyzed with mass spectrometry (ICP-MS) for its elemental analysis; with electronic microscopy (SEM, TEM) and energy dispersive X-ray (EDX) analysis to analyze the different organs, tissues and cell content; and with X-ray diffraction (XRD) to identify the possible biomineral production.

Results: I. cylindrica specimens reached 4805, 7976 and $53886 \mathrm{Fe} \mathrm{mg/kg} \mathrm{d.w.} \mathrm{in} \mathrm{leaves,} \mathrm{rhizomes} \mathrm{and} \mathrm{roots}$ respectively. Fe was visible as a plaque in the root and as deposits inside all the organs. Part of these accumulations corresponds to crystallized jarosite and iron oxides.

Conclusions: We induced Fe hyperaccumulation and biomineralization in I. cylindrica under specific controlled conditions. Considering this we think this species could be an interesting candidate to phytoremediate soils.

Keywords: Iron bioformations; Jarosite; Imperata cylindrica; Iron oxides; Iron plaque

\section{Introduction}

Imperata cylindrica (L.) P. Beauv. is a perennial helophyte grass with a highly developed and branched rhizome. This rhizomatous system can reach depths of more than $50 \mathrm{~cm} \mathrm{[1]} \mathrm{and} \mathrm{represents} \mathrm{at} \mathrm{least} 60 \%$ of the total plant biomass [2]. The leaves are $40-90 \mathrm{~cm}$ long and $2 \mathrm{~cm}$ wide, growing grouped at the nodes of the rhizome.

I. cylindrica is native to Southeast Asia, Australia, China, Japan and the Philippines and widely distributed throughout the Mediterranean area. It is very resistant to droughts and floods, and it is found in a variety of soils, from strongly acidic to slightly alkaline.

In the south of the Iberian Peninsula it grows in riparian ecosystems, small streams, moist sandy banks and gullies, subdued to severe summer droughts. It could be found growing in the river banks of the Tinto River (Southwestern Iberian Peninsula, Spain) [3], an extremely acidic environment with high $\mathrm{Fe}$ and other metal concentrations in water and soils [4].

Iron toxicity is enhanced by low $\mathrm{pH}$ values, which cause $\mathrm{Fe}$ dissolution and increased bioavailability [5]. In low $\mathrm{pH}$ environments such as the Tinto River basin, plants are subdued to a strong abiotic stress, generating hydroxyl radicals that cause cellular damage. Nevertheless, $\mathrm{Fe}$ is essential for plant growth, photosynthesis and $\mathrm{CO}_{2}$ fixation, being usually a limiting factor in environments with higher $\mathrm{pH}$ values. Iron homeostasis is therefore a very dynamic and strictly regulated process, and different plant strategies to deal with the lack or excess of Fe in the substrate could be found $[6,7]$.

Previous studies in I. cylindrica using Inductive Coupled Plasma Mass Spectrometry (ICP-MS) reported Fe concentration values of about $1 \%$ of plant dry weight $[8,9]$. By means of Mössbauer spectrometry and X-ray diffraction, Rodríguez et al. [8] identified the iron content of $I$. cylindrica as ferrihydrite and jarosite at a proportion of $50 \%$, respectively, within roots, rhizomes and leaves of the plant. Those biominerals have been observed in the cells of the epidermis; parenchyma and vascular bundles. Amils et al. [10] and Fuente et al. [11] interpret these particles as a result of degradation of ferritin protein metabolism, which stores in its core ferrihydrite, hematite and magnetite [12-15]. A more detailed localization of the subcellular distribution of ferritin using immunocytochemical techniques was described by Fuente et al. [11].

In this article we focus on the study of the Fe absorption capacities of $I$. cylindrica to reproduce its hyperacummulation under controlled conditions in the laboratory, locating places of $\mathrm{Fe}$ accumulation, and identifying the different structures of Fe compounds formed inside the organs of the plant.

\section{Materials and Methods}

\section{Plant material}

Complete individuals of $I$. cylindrica were collected directly from the riverside communities of Tinto River, near La Palma del Condado and Niebla (Huelva, Spain), selecting those best preserved and similar in size. Sections of the rhizomes were separated, cleansed with distilled water and planted in pots with universal substrate to be grown in the greenhouse.

*Corresponding author: Vicenta de la Fuente, Dpto. Biología, Facultad de Ciencias, Universidad Autónoma de Madrid, E-28049 Madrid, Spain, Tel: 0034914978100 E-mail: vicenta.fuente@uam.es

Received October 27, 2015; Accepted November 11, 2015; Published November 22, 2015

Citation: Franco A, Rufo L, Fuente Vdl (2015) Fe Absorption and Distribution of Imperata cylindrica (L.) P. Beauv. under Controlled Conditions. J Environ Anal Toxicol 5: 335. doi:10.4172/2161-0525.1000335

Copyright: $\odot 2015$ Franco A, et al. This is an open-access article distributed unde the terms of the Creative Commons Attribution License, which permits unrestricted use, distribution, and reproduction in any medium, provided the original author and source are credited. 
After a growth period of 12 months in the greenhouse, the resulting plants were removed, cleansed of all residues and transferred to a pure hydroponic culture in Hoagland solution ( $\mathrm{pH}$ 5.1). This nutrient medium was enriched with $300 \mathrm{mg} / \mathrm{Kg}$ of Fe. To avoid Fe precipitation, the $\mathrm{pH}$ of the solution was lowered to 3 using $\mathrm{H}_{2} \mathrm{SO}_{4}[1 \mathrm{M}]$. The culture was maintained in the greenhouse with natural light and a controlled temperature of $30^{\circ} \mathrm{C}$.

Samples were collected each fortnight $(15,30,45$ and 60 days) during two months, with a sample taken before treatment (0 days). Each sample consisted of three entire plants that were separated in root, rhizome and leaves, washed and frozen until analysis.

\section{Elemental analysis}

Plant samples were washed with distilled water, dried in an oven at $75^{\circ} \mathrm{C}$ for $24 \mathrm{~h}$ and powdered for homogenization. Small portions of dry plant tissues powder $(500 \mathrm{mg})$ were digested at high pressure in a mixture of $8 \mathrm{ml}$ of $\mathrm{HNO}_{3} 65 \%$ and $2 \mathrm{ml}$ of $\mathrm{H}_{2} \mathrm{O}_{2} 30 \%$ in a MLS Ethos 1600 URM Milestone microwave digester, following the protocol described by Zuluaga et al. [16]. Aliquots of the different samples were analyzed by ICP-MS using an ELAN-6000 PE-Sciex (Toronto, Ontario, Canada) instrument. The ICP-MS technique used has an inherent error of $15 \%$.

\section{Microscopy analysis}

Scanning Electron Microscopy (SEM - EDX): Three specimens of cultivated I. cylindrica for each sampling time were analyzed by SEM complemented with an Energy Dispersive X-ray analyzer (EDX) following the protocol for elemental analysis and metal localization study in plant material $[8,10,11,17]$. The organs and tissues analyzed were; roots (epidermis, parenchyma, endodermis and pith), rhizome (epidermis, cortex, central cylinder and pith) and leaves (cuticle, epidermis, trichomes, parenchyma and vascular bundles). Samples were mounted onto conductive graphite stubs and sputters then goldcoated in a BIO-RAD SC 502 apparatus to ensure electrical conductivity and prevent charging under electron beams. Samples were examined with a Hitachi S-3000N (Japan) SEM using an acceleration voltage of $20 \mathrm{kV}$ and a working distance of $15 \mathrm{~mm}$. Analyses were performed at room temperature. The qualitative element composition of samples was determined using an INCAx-sight with a Si-Li Detector (Oxford, England) with a detection limit of $10 \%$ of the main element.

Transmission Electron Microscopy (TEM - EDX): Root and rhizome samples of three specimens of wild and cultivated I. cylindrica were analyzed by TEM. Those organs were selected because of their high Fe concentration. Small sections $\left(1 \mathrm{~mm}^{3}\right)$ of roots and rhizomes from I. cylindrica were fixed in $4 \%$ paraformaldehyde and $2 \%$ glutaraldehyde in $0.05 \mathrm{M}$ cacodylate buffer ( $\mathrm{pH}$ 7.4) for 2 hours at room temperature. Fixed samples were washed three times in the same buffer and postfixed with $1 \% \mathrm{OsO}_{4}$ in water for $30 \mathrm{~min}$ at room temperature in the dark. After three washes in bidistillated water samples were incubated with $2 \%$ aqueous Uranil Acetate for $1 \mathrm{~h}$ at room temperature, washed again and dehydrated in increasing concentrations of ethanol 30, 50 and $70 \%$ $20 \mathrm{~min}$ each, $90 \% 2 \times 20 \mathrm{~min}$ and $100 \% 2 \times 30 \mathrm{~min}$ at room temperature. Dehydration was completed with a mixture of ethanol: propylene oxide (1:1) for $10 \mathrm{~min}$ and pure propylene oxide $3 \times 10 \mathrm{~min}$. Infiltration of the resin was accomplished with propylene oxide:Epon (1:1) for 45 min and pure Epoxy (TAAB 812 Resin; TAAB Laboratories, Berkshire, England) resin over night at room temperature. Polymerization of infiltrated samples was done at $60^{\circ} \mathrm{C}$ for 2 days. Ultrathin sections of the samples were stained with uranyl acetate and lead citrate by standard procedures.

Samples were examined at $80 \mathrm{Kv}$ in a Jeol JEM-1010 (Tokyo, Japan) electron microscope (Centro de Biología Molecular, CSIC, Madrid, Spain) and a JEM 2000FX electron microscope (Tokyo, Japan) operated at $200 \mathrm{kV}$ (Centro Nacional de Microscopía Electrónica, Madrid, Spain) equipped with an energy dispersive X-Ray microanalysis instrument LINK ISIS 300 (Oxford, England).

\section{Mineralogy study}

X-ray Diffraction (XRD): Dried and powdered samples of root and rhizome of 60 days cultivated I. cylindrica were analyzed to obtain an X-ray diffraction pattern, using a Siemens-D5000 (Siemens AG, Karlsruhe, Alemania) analyzer with $\mathrm{Cu} \mathrm{Ka}$ radiation $(8.04 \mathrm{keV})$, a Si-Li detector provided by Kevex (Valencia, CA, USA) and cooled by Peltier effect, allowing resolutions up to $240 \mathrm{eV}$ [18].

\section{Statistical analysis}

Statistical analyses were carried out using Statistical release 6.0 (Statsoft Inc., Tulsa, USA). Means, medians, standard deviations, and standard errors were calculated. Data were log transformed after being tested for normality with the Shapiro-Wilk test $(p>0.05)$. Different translocation coefficients (TC) were calculated as:

$$
\begin{aligned}
& \mathrm{TC}_{\mathrm{L} / \mathrm{Rz}=}[\mathrm{M}]_{\text {leaf }} /[\mathrm{M}]_{\text {rhizome }} \\
& \mathrm{TC}_{\mathrm{Rz} / \mathrm{R}=}[\mathrm{M}]_{\text {rhizome }} /[\mathrm{M}]_{\text {root }} \\
& \mathrm{TC}_{\mathrm{L} / \mathrm{R}=}[\mathrm{M}]_{\text {leaf }} /[\mathrm{M}]_{\text {root }}
\end{aligned}
$$

\section{Results}

\section{Elemental analysis (ICP-MS)}

Leaf: The mean Fe concentration of the leaves at 0 days was 304.1 $\mathrm{mg} / \mathrm{kg}$ d.w. From that point, the concentration increased significantly $(p<0.05)$ along the experiment, reaching $4805 \mathrm{mg} / \mathrm{kg} \mathrm{d.w}$. at the final sampling (Table 1).

Rhizome: At the beginning of the experiment (day 0), the Fe concentration of the rhizomes was $172.1 \mathrm{mg} / \mathrm{kg}$ d.w. After the first 15 days, the concentration reached $2081 \mathrm{mg} / \mathrm{kg}$ d.w. and remained without significant changes for 30 days. During the last fortnight of the treatment, the concentration increased until $7976 \mathrm{mg} / \mathrm{kg}$ d.w. at day 60 .

Root: The initial mean concentration of $\mathrm{Fe}$ in the roots was 193.3 $\mathrm{mg} / \mathrm{kg}$ d.w. before the treatment. Fe concentration reached $8524 \mathrm{mg} / \mathrm{kg}$ d.w. at the first 15 days, and continued increasing during the experiment until values of $53886 \mathrm{mg} / \mathrm{kg}$ d.w. at the last day of the experiment.

There are no significant differences in the $\mathrm{Fe}$ concentrations measured before the treatment (day 0 ) between leaves, rhizomes and roots. The translocation coefficients (Table 2) indicate that, at the end of the experiment, the distribution of Fe concentration between organs was in the order: roots $>$ rhizomes $>$ leaves. Nevertheless, Fe concentration between rhizomes and leaves was not significantly different $(p>0.05)$ along all the measured samples.

\section{Scanning Electron Microscopy (SEM)}

Plants grew during the experimental process, but the growth rate of the different organs differed. While there was leaf production, these were scarce and small, and did not reach their normal size in their natural habitat. However, root and rhizome were totally developed being the roots the organ with the highest rate of growth. The microscopic analysis of all the organs revealed that the tissues were well 
Citation: Franco A, Rufo L, Fuente Vdl (2015) Fe Absorption and Distribution of Imperata cylindrica (L.) P. Beauv. under Controlled Conditions. J Environ Anal Toxicol 5: 335. doi:10.4172/2161-0525.1000335

Page 3 of 7

\begin{tabular}{|c|c|c|c|c|c|c|}
\hline & & $\mathbf{0}$ days & $\mathbf{1 5}$ days & $\mathbf{3 0}$ days & $\mathbf{4 5}$ days & $\mathbf{6 0}$ days \\
\hline Leaf & $\mathrm{M}$ & $304.1^{\mathrm{a} / 1}$ & $1225^{\mathrm{b} / 1}$ & $2580^{\mathrm{bc} 1}$ & $2902^{\mathrm{bc} / 1}$ & $4805^{\mathrm{c} / 1}$ \\
\hline & $\mathrm{SD}$ & 171.1 & 260.1 & 551.7 & 1272 & 1518 \\
\hline Rhizome & $\mathrm{M}$ & $172.1^{\mathrm{a} / 1}$ & $2081^{\mathrm{b} / 1}$ & $1862^{\mathrm{b} / 1}$ & $2449^{\mathrm{b} / 1}$ & $7976^{\mathrm{d} / 1}$ \\
\hline & $\mathrm{SD}$ & 58.83 & 1126 & 144.1 & 427.9 & 822.6 \\
\hline Root & $\mathrm{M}$ & $193.3^{\mathrm{a} / 1}$ & $8524^{\mathrm{b} / 2}$ & $14,760^{\mathrm{bc} / 2}$ & $21,976^{\mathrm{d} / 2}$ & $53,886^{\mathrm{d} / 2}$ \\
\hline & $\mathrm{SD}$ & 87.52 & 2028 & 2183 & 6615 & 12,895 \\
\hline
\end{tabular}

Table 1: Means (M) and standard deviation (SD) of Fe concentration values (mg/ $\mathrm{kg}$ d.w.) of Imperata cylindrica leaves, rhizomes and roots along the experiment. Super-index letters codify significant differences in mean values between days, while numbers codify significant differences in mean values between plant organs $(p<0,05), n=3$.

\begin{tabular}{|c|c|c|c|c|c|}
\hline & $\mathbf{0}$ days & $\mathbf{1 5}$ days & $\mathbf{3 0}$ days & $\mathbf{4 5}$ days & $\mathbf{6 0}$ days \\
\hline Leaf/Rhizome & 1.77 & 0.589 & 1.39 & 1.19 & 0.603 \\
\hline Rhizome/Root & 0.890 & 0.244 & 0.126 & 0.111 & 0.148 \\
\hline Leaf/Root & 1.57 & 0.144 & 0.175 & 0.132 & 0.089 \\
\hline
\end{tabular}

Table 2: Translocation Coefficients between different organs of $I$. cylindrica along the exposition period.

preserved maintaining a good structural integrity of the organs along the experiment, in spite of the hard experimental conditions (Figures $1-3)$.

Root: A progressive mineral deposition is observed over the epidermal cells of the roots along the experiment, from no depositions at all (Figure $1 \mathrm{~A}$ and $\mathrm{E}$ ) to a thick plaque that covers almost all the cell surface (Figure $1 \mathrm{~F}$ and $\mathrm{G}$ ). The formation of this plaque is observed not only in the external surface of the root, in contact with the treatment solution, but also in the internal tissues of the root, where we could observe collapsed cells (Figure 1 B and C). The EDX analysis shows a composition of $\mathrm{Fe}, \mathrm{S}$ and $\mathrm{K}$ with occasional traces of $\mathrm{Ca}, \mathrm{Si}$ and $\mathrm{P}$, in both the apoplast and inside cell depositions.

The parenchymatous cells also shows a progressive accumulation of Fe (Figure $1 \mathrm{H}$ and I), resulting in the presence of numerous collapsed cells at the final stages of the experiment. Those iron deposits were also observed over the cells walls and in the intercellular space (Figure 1 $\mathrm{H}, \mathrm{I}, \mathrm{J})$. Near the end of the experiment, the number and density of those iron deposits were higher in the younger roots than in the roots that started growing at earlier stages of the treatment. Although the Fe observed accumulations were generally amorphous, some isolated particles showed a more defined structure (Figure $1 \mathrm{~K}$ ).

In the endodermis cells between the root cortex and the vascular cylinder we have not detected any iron accumulation though some silicon deposits are observed in the cross section of old roots (Figure $1 \mathrm{D}$ and $\mathrm{H}$ ). At the beginning of the experiment, the central cylinder and the vascular tissues were almost free from Fe particles, but those particles increased in number and size along the experiment, especially in the xylem vessels (Figure $1 \mathrm{D}, \mathrm{H}$ and I).

Rhizome: Representative micrographs of rhizome observations are shown in Figure 2. Analyzed tissues were: epidermis, parenchyma and central cylinder with vascular bundles (Figure $2 \mathrm{~A}$ ). Fe accumulations have been observed inside xylem vascular vessels (Figure $2 \mathrm{~B}$ ) as well as in the cortex parenchyma cells (Figure $2 \mathrm{C}$ and $\mathrm{D}$ ). We also observed the presence of lenticular particles, isolated or in groups (Figure $2 \mathrm{E}$ and $F$ ) and some prismatic particles (Figure $2 \mathrm{G}$ ). In the epidermis cells we detected a discontinuous Fe plaque over the surface as well as

numerous collapsed cells (Figure $2 \mathrm{H}$ and I). The EDX spectra show again a composition of $\mathrm{Fe}, \mathrm{S}$ and $\mathrm{K}$.

Leaf: Micrographs from leaf sections (Figure 3) also show the presence of Fe particles in the parenchyma around the vascular bundles, and the abaxial and adaxial epidermal cells (Figure $3 \mathrm{~A}, \mathrm{~B}$ and C). Those particles appear in less numbers than in other organs, but almost all of them are of lenticular or prismatic shape (Figure $3 \mathrm{D}$ ). There is also an increase in the appearance of $\mathrm{Fe}$ particles along the experiment. The EDX spectra show a composition mainly of Fe, $\mathrm{S}$ and $\mathrm{K}$, with traces of $\mathrm{P}, \mathrm{Si}, \mathrm{Ca}$ and $\mathrm{Mg}$ in some of them.

Figure 4 represents the mean values of Fe weight percentage obtained in the EDX spectra analysis over the different accumulations that we found in the tissues of roots, rhizomes and leaves. The analyses were separated in epidermis, cortex, and vascular cylinder Fe accumulations. Fe particles over epidermal cells of older roots show a higher Fe weight percentage than the same particles found in the youngest roots grown during the experiment, whilst the particles found inside the cortical tissues show a lower $\mathrm{Fe}$ weight percentage value $(p<0.05)$. Mineral depositions found in the rhizomes and leaves have a similar Fe weight percentage in all analyzed tissues.

\section{Transmission Electron Microscopy (TEM)}

Root and rhizomes of wild and cultivated I. cylindrica were observed by TEM and a selection of representative micrographs can be found in Figure 5.

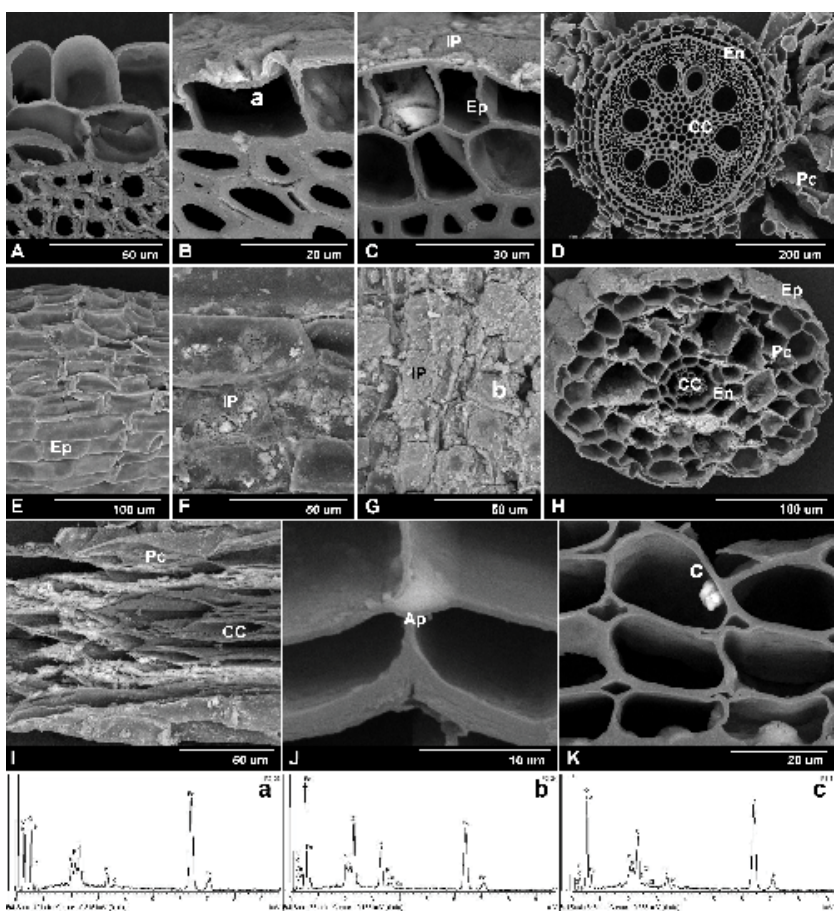

Figure 1: Representative SEM micrographs of $l$. cylindrica roots. (Ep=epidermis; IP=iron plaque; En=endodermis; $\quad \mathrm{PC}=$ parenchyma; $\mathrm{CC}=$ central cylinder; $\mathrm{Ap}=$ apoplast $) . \mathbf{A}-\mathrm{C} \mathrm{Fe}$ acumulation in epidermis cells over time $(0-30-60$ days). D Transversal section of the central cylinder. E-G Iron plaque formation over epidermal surface during the experiment $(0$ $-30-60$ days). $\mathbf{H}$ Transversal section of young root with collapsed cortex cells. I longitudinal section of young root with $\mathrm{Fe}$ accumulations in the cortex cells. J Fe accumulation in cortex apoplast. $\mathbf{K}$ Fe particle in cortex. EDX spectra correspond to points $a, b$ and $c$ of figures $B, G$ and $K$ respectively. 
Citation: Franco A, Rufo L, Fuente Vdl (2015) Fe Absorption and Distribution of Imperata cylindrica (L.) P. Beauv. under Controlled Conditions. J Environ Anal Toxicol 5: 335. doi:10.4172/2161-0525.1000335

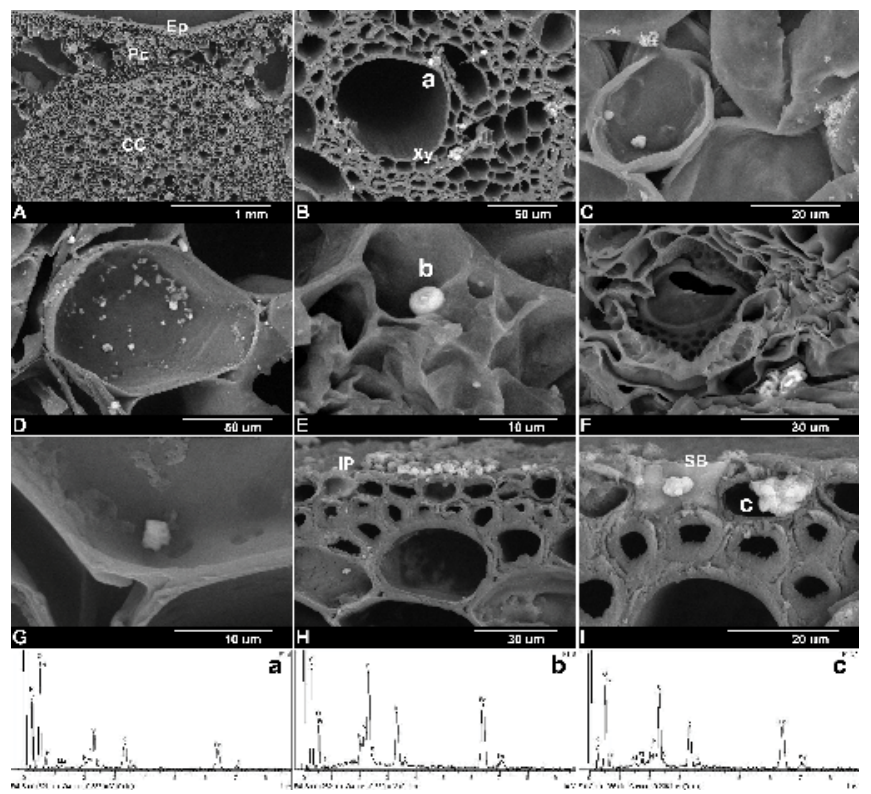

Figure 2: Representative SEM micrographs of $I$. cylindrica rhizomes. (Ep=epidermis; Pc=parenchyma; $\mathrm{CC}=$ central cylinder; $\mathrm{Xy}=\mathrm{xylem}$; IP=iron plaque; $\mathrm{SB}=$ silica body). A Transversal section of rhizome. B Detail of central cylinder vascular bundle with Fe particles. C-D Detail of cortex parenchymatous cells with Fe mineral accumulations. E Lenticular Fe biomineralization inside vascular bundle. $\mathbf{F}$ Lenticular Fe particles accumulation. G Prismatic-shaped Fe mineral in parenchyma cells. $\mathbf{H}$ Iron plaque over the epidermis. I Epidermal cell collapsed with Fe near a silica body. EDX spectra correspond to points $a, b$ and $c$ of figures $B, E$ and I respectively.

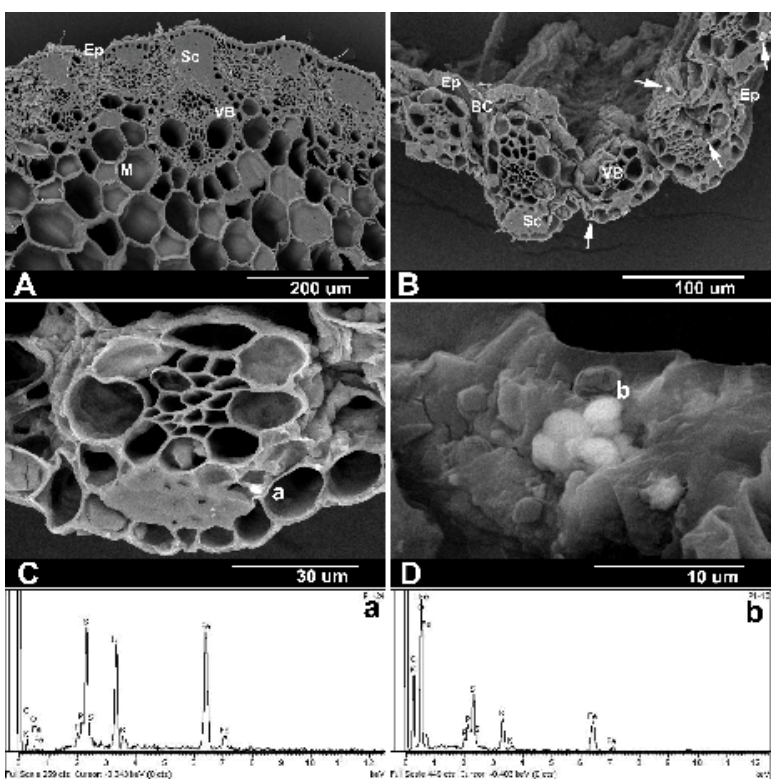

Figure 3: Representative SEM micrographs of $I$. cylindrica leaves. (Ep=epidermis; Sc=sclerenchyma; VB=vascular bundle; $M=$ =mesophyll; $\mathrm{BC}=$ bulliform cells). A Transversal section of leaf showing the midrib. B Transversal section of leaf with Fe particles. C Detail of vascular bundle with Fe particles. D Detail of lenticular Fe particles near vascular bundle. EDX spectra correspond to points $a$ and $b$ of figures $C$ and $D$ respectively.

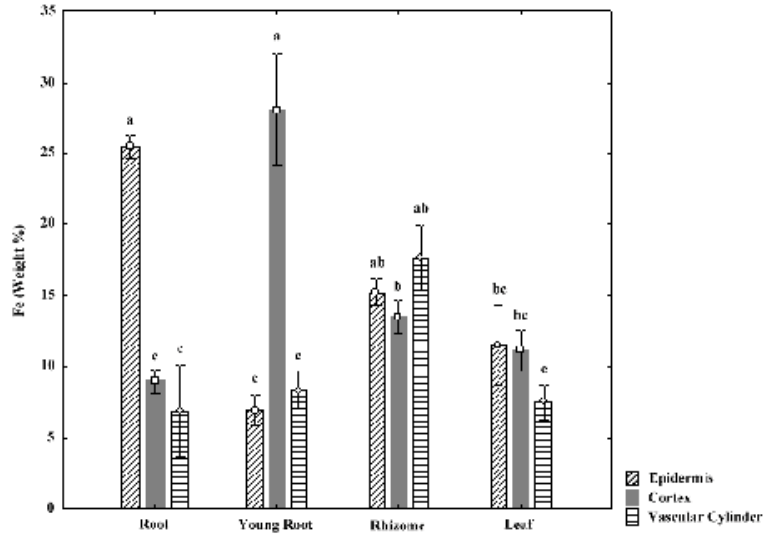

Figure 4: Mean of Fe weight percentage from EDX analysis of mineral accumulations found in roots, young roots, rhizomes and leaves of $I$. cylindrica by SEM. $\mathrm{N}=3$. Lower case letters represent significant statistical differences between mean values.

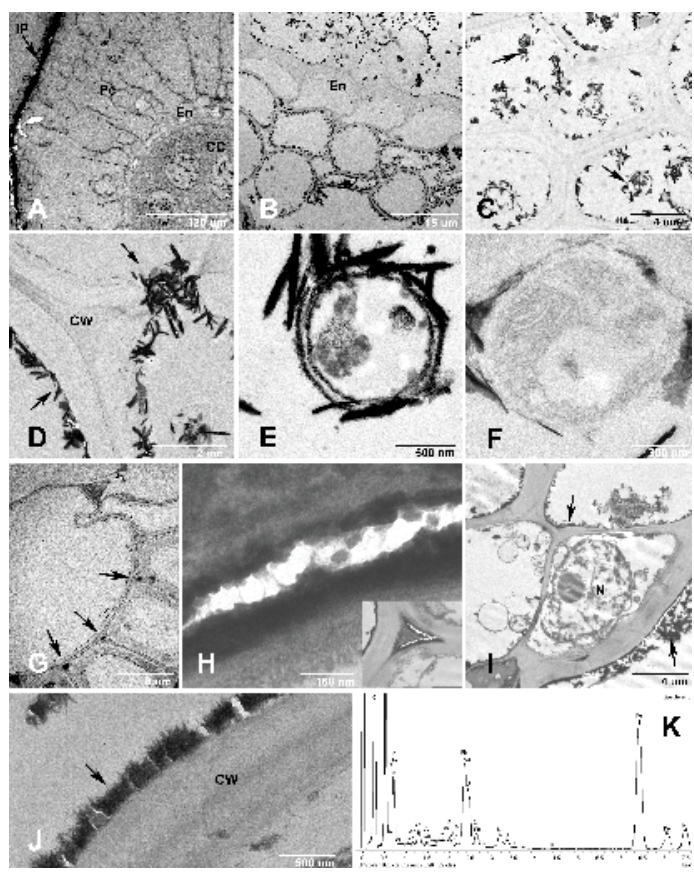

Figure 5: Representative TEM micrographs of $I$. cylindrica. (IP=iron plaque; $\mathrm{Pc}=$ parenchyma; $\mathrm{En}=$ endodermis; $\mathrm{CC}=$ central cylinder; $\mathrm{CW}=$ cell wall; $\mathrm{N}=$ nucleus). A Root transversal section. Iron plaque over the epidermis and Fe deposits in cortex and central cylinder. B Detail of root endodermis, Fe particles in cortex and central cylinder. $\mathbf{C}$ Organelles and cell walls covered with $\mathrm{Fe}$ in the roots. D Detail of Fe spicules passing through the cell wall in the root. E Organelle (plastid) with its membranes covered with Fe and Fe spicules. Fe deposits could also be seen inside it. $\mathbf{F}$ Detail of organelle (plastid). $\mathbf{G}$ and $\mathbf{H}$ Localization and detail of intercellular spaces filled with Fe nanoparticles in the vascular bundle sheath of rhizome. I Transversal section of rhizome with Fe particles covering the cell walls. $J$ Detail of cell wall covered with Fe particles and spicules, in the root of a full-grown Imperata cylindrica from the Tinto River. K Representative EDX spectrum from Fe particles. 
The root cross section allows identifying all the principal tissues in this organ and confirms their good state (Figure $5 \mathrm{~A}$ ). The iron plaque previously observed by SEM is visible here in the outer side of the epidermal cells as a thick black discontinuous line (Figure $5 \mathrm{~A}$ ). The cortex is composed of big cortical cells with fine cell walls which represent most of the volume of the root (Figure $5 \mathrm{~A}$ ). These have a scarce number of organelles such as plastids, vacuoles, nuclei and mitochondria (Figure $5 \mathrm{E}$ and $\mathrm{F}$ ). Most of these cells present a high proportion of black and long deposits grouped forming an almost continuous layer along the inner side of the cell wall (Figure $5 \mathrm{~B}$ ). This electro-dense material can be found also covering the outer membrane of the organelles (Figure $5 \mathrm{E}$ ).

The cortex is followed by a layer of cells with thickened walls, the endodermis, which separates the cortex from the central cylinder. This is the only tissue free from the black particles (Figure $5 \mathrm{~B}$ ). The central cylinder includes several types of cells as the phloem and xylem vessels alternated with parenchymatous cells. Here we also find the dark deposits covering the inner side of the cells walls and the outside of the organelles when present (Figure $5 \mathrm{C}$ ). These deposits are so abundant that even collapsed the pores and plasmodesmata that communicate cell to cell (Figure $5 \mathrm{D}$ ).

These long dark deposits are also visible in the rhizome with the same distribution (Figure $5 \mathrm{I}$ ). Moreover, we also observed darkened intercellular spaces (Figure $5 \mathrm{~F}$ and $\mathrm{H}$ ) composed of electro-dense particulate material (Figure $5 \mathrm{H}$ ).

All these observation carried out in cultivated material were corroborated in wild samples. An example is provided in Figure $5 \mathrm{~J}$ where a root cell wall of wild full grown I. cylindrica specimens shows a cover of long dark deposits which composition includes a high proportion of $\mathrm{Fe}$ as reveals the EDX analysis (Figure $5 \mathrm{~K}$ ). This layer is even thicker than that found in the experimental samples.

\section{X-ray Difracction}

XRD analysis spectra are represented in Figure 6. They indicate the presence of jarosite and $\mathrm{Fe}$ oxides in both roots and rhizomes of $I$. cylindrica cultivated during 60 days in Fe enriched Hoagland solution. The spectra also show the presence of opal crystals $\left(\mathrm{SiO}_{2}\right)$ possibly corresponding to the silica deposits observed in the endodermic cells, and some gypsum crystals $\left(\mathrm{CaSO}_{4} \cdot \mathrm{H}_{2} \mathrm{O}\right)$ in both roots and rhizomes.

\section{Discussion}

This is the first report of the production under laboratory controlled condition of the biomineralization of jarosite and Fe oxides and oxihydroxides by I. cylindrica. Though Fe accumulation is known in several species of Graminae growing in Tinto River (Phragmites australis, Panicum repens, Arundo donax) and species of other families (Typha angustifolia, Erica andevalensis) none of them reach $\mathrm{Fe}$ concentrations of $I$. cylindrica nor have been found to biomineralize jarosite $[9,19]$.

After 60 days of treatment with the Fe enriched solution, high concentrations of Fe could be found inside I. cylindrica tissues. That concentration was higher in the roots and rhizomes than in the leaves, in consonance with the results obtained by Rodríguez et al. [8] in field grown individuals. Since the second fortnight of treatment, $I$. cylindrica reached Fe concentrations higher than the normal values given for vascular plants by Reeves and Baker [20]. In particular, root $\mathrm{Fe}$ concentration was over phytotoxic levels $(1000-3000 \mathrm{mg} / \mathrm{kg}$, [21]) since the first week, and after the 60 days of treatment reached concentration
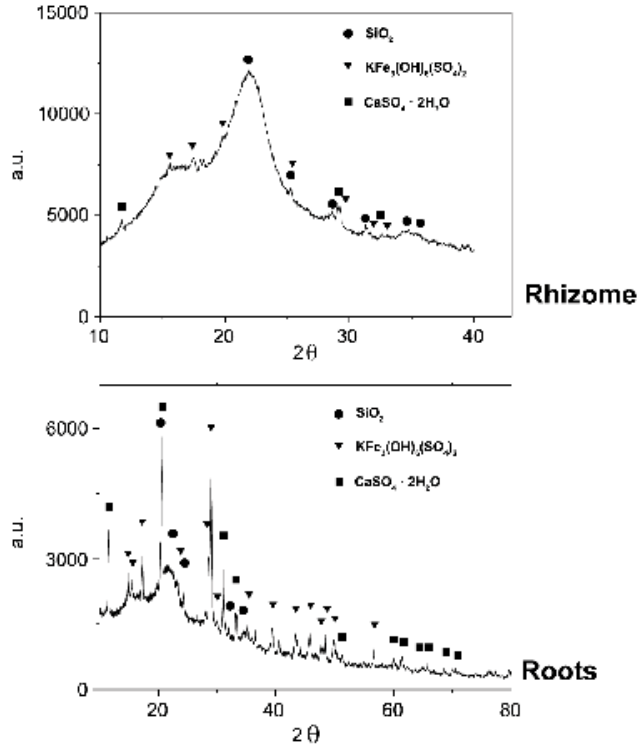

Figure 6: XRD spectra of rhizomes and roots of cultured Imperata cylindrica showing the presence of $\mathrm{SiO}_{2}$ (opal), $\mathrm{KFe}_{3}(\mathrm{OH})_{6}\left(\mathrm{SO}_{4}\right)_{2}$ (jarosite) and $\mathrm{CaSO}_{4} \cdot 2 \mathrm{H}_{2} \mathrm{O}$ (gypsum).

values that could be considered as hyperaccumulation. Rhizomes and leaves reached $\mathrm{Fe}$ concentrations over the phytotoxic levels in the last sampling day, but concentrations remained in range with values given for other non hyperaccumulator plants adapted to metalliferous environments.

During the experiment the plants grew. The organ that exhibited the fastest rate of growth was the root. The continuous production of roots and $\mathrm{Fe}$ accumulation in their surface (iron plaque) and tissues may be part of a protection strategy to cope with the excess of $\mathrm{Fe}$ and prevent a dangerous increase of $\mathrm{Fe}$ concentrations in rhizomes and leaves. The importance of root tissues in heavy metal retention and tolerance has been widely studied [22-26]. This behavior has been found in other plant species, such as Phragmites australis [27] and Cynodon dactylon [19], in which the Fe retention in roots is probably the most relevant strategy in rhizome protection against oxidative stress. Taggart et al. [28] also found an increase in the production of secondary roots in Typha latifolia under extreme conditions.

However, leaves growth was slow, and they did not reach the usual size in natural conditions. This may indicate that the excess of Fe may affect somehow to the plant regular growth. Healthy plants but smaller have been observed in several species growing on Tinto River, when compared with those growing in other habitats less rich in metals [9]. The small plant size has been also emphasized as a feature of serpentine flora; another particular flora specialized in naturally metalliferous soils [29]. Nevertheless, the high concentrations of Fe found in rhizomes and leaves without any structural damage that could compromise its growth and functions, indicates that even when there is a high Fe root retention, these tissues should be highly tolerant to Fe excess, probably due to the existence of other simultaneous tolerance/detoxification mechanisms.

Though SEM-EDX technique has been proved as a good system to localize and analyze metals inside plant organs, the observation of massive biomineralization by TEM is not as usual, probably due in 
part to the inherent complications of sample preparation. The high $\mathrm{Fe}$ concentration in roots and rhizomes of I. cylindrica has allowed the visualization at cellular level of the biomineralization of this metal. In this regard, SEM and TEM combination has been useful to observe Fe accumulation and biomineralization and its distribution at tissular and cellular level.

The high Fe concentration of the roots was observed as an iron plaque in the epidermis by SEM and TEM. EDX analysis indicated a composition of $\mathrm{Fe}, \mathrm{S}, \mathrm{K}$ and $\mathrm{P}$, suggesting the presence of the mineral jarosite that was confirmed by means of XRD. Therefore, we reproduced the formation of a similar iron plaque that the one formed by field individuals [8]. We should indicate though that iron plaques of different species have been intensively studied and has been found that their composition is pretty variable among species and even among ecotypes [30-34]. Iron plaques of other Tinto River Graminae such as Cynodon dactylon have high Fe concentrations, but no jarosite was found [19].

Fe deposits were observable by SEM in almost all the tissues composed of $\mathrm{Fe}, \mathrm{S}$ and $\mathrm{K}$ inside the epidermal and cortical cells, and the xylem and phloem vessels in the vascular cylinder on roots and rhizomes. Those deposits appeared in form of isolated particles, grouped particles, and fully collapsed cells. The number and density of those deposits were higher in the younger roots. By other hand, the vascular tissues increased their Fe deposits as the increased the time of exposition. TEM images allow the detection of black and long deposits composed mainly by $\mathrm{Fe}$ and located in the inner side of the cell walls, surrounding the organelles and also in the intercellular space of almost all root tissues. These could be Fe oxides according to the XRD spectra. The presence of ferritin has been reported in roots, rhizomes and leaves of I. cylindrica by means of immunocytochemical analysis [11]. The degradation of this protein could derive in the formation of the iron oxides.

The endodermis was the only root tissue that was found to be free of Fe deposits. The endodermis is composed by cells with some part of their wall chemically modified in order to control the pass of water and ions to the central cylinder and therefore to the xylem and the rest of the organs. It seems that at the beginning it provides an efficient barrier, thus Fe depositions are almost inexistent in the central cylinder. But as the exposition to high Fe concentration in the solution carries on Fe deposits are more abundant in the central cylinder. TEM images showed the same deposits, with the same structure at both sides of the endodermis. Interestingly, endodermis cells remain free of Fe deposition, indicating their continuous activity transferring $\mathrm{Fe}$ to the central cylinder tissues where Fe can be transported or somehow retained leading to biomineralization. Abundant $\mathrm{Fe}$ deposits were found in root and rhizome xylem vessels by SEM technique, especially at the end of the experiment. This coincides with the field observations reported by Rodríguez et al. [8] who found pores of xylem elements totally collapsed by $\mathrm{Fe}$ biominerals. Previous observations on $I$. cylindrica roots showed silicon deposits on the proximal site of the endodermis cells [35]. Here, these were not visible in TEM because of the youth of the roots observed, though incipient silicon deposits were observed by SEM in older roots. Whether or not silicon and iron transport in the plant may be somehow related is unknown, but the fact is that whilst silicon is deposited in the endodermis cells, iron is not.

So even though I. cylindrica is a Fe hyperaccumulator, it presents a strategy of $\mathrm{Fe}$ retention in roots, and a regulation over the $\mathrm{Fe}$ translocation to aerial parts and reserve tissues (in the rhizome). Nevertheless all of the plant aerial and underground tissues have and tolerate a high Fe concentration. Our study suggests that internal biomineralization plays an important role in this tolerance, reducing metal toxicity.

The ease of growth and reproduction of I. cylindrica, and its rapid development of a dense rhizomatous system, allow for a high production of biomass, which implies a higher immobilization of $\mathrm{Fe}$. The fact that its rhizomatous system could reach deeps of $50 \mathrm{~cm}$ [36] also allows for a great stabilization of the soil and the decontamination of deeper soil layers impossible to reach with other gramineous species.

I. cylindrica is also tolerant to other numerous heavy metals such as $\mathrm{Pb}$ [37], Cu, Zn, Sn [38], Cr, Ni and Co [39], with an excluding strategy, and it have also been found colonizing highly polluted environments like $\mathrm{Pb}-\mathrm{Zn}$ mines $\mathrm{Zn}[40,41]$. These characteristics make I. cylindrica a species to take into account in contaminated soil stabilization programs, as it retains the highest metal concentrations in the roots, less accessible to feeding animals. Moreover, we have reproduced its hyperaccumulator behavior under controlled conditions, also achieving the bioformation of jarosite and Fe oxides in the laboratory. The control of these capabilities could be also useful for the employment of this species for the production of Fe biominerals and nanoparticles with diverse utilities (medicine, biomaterials, nanotechnology).

\section{Acknowledgements}

The authors would like to thank the personnel of the Centro Nacional de Microcopía, the transmission electron microscopy service of the Centro de Biología Molecular, and the ICP-MS analysis service of the UCM CAI-Técnicas Geológicas.

\section{References}

1. MacDonald GE, Brecke JB, Gaffney JF, Langeland KA, Ferrell JA et al. (2006) Cogongrass (Imperata cylindrica (L.) Beauv.) Biology, Ecology and Management in Florida. SS-AGR-52. Institute of Food and Agricultural Sciences, University of Florida.

2. Sellers BA, Ferrell JA, MacDonald GE, Langeland KA, Flory SL (2012) Cogongrass (Imperata cylindrica) Biology, Ecology, and Management in Florida Grazing Lands. SS-AGR-52. Institute of Food and Agricultural Sciences, University of Florida.

3. Rufo L, Fuente V (2011) Vegetación herbácea vivaz de la cuenca del río Tinto (Huelva, España). Lazaroa 32: 73-89.

4. Amils R, González-Toril E, Gómez F, Fernández-Remolar D, Rodríguez N, et al. (2004) Importance of chemolithotrophy for early life on earth: The Tinto River (Iberian Pyritic Belt) Case. In: Seckbach J (ed) Origins: Genesis, Evolution and Diversity of Life. Kluwer Academic Publishers, Dordrecht, The Netherlands. pp 463-480.

5. Briat JF, Lobréaux S (1997) Iron transport and storage in plants. Trends Plant Sci 2: 187-193.

6. Palmer CM, Guerinot ML (2009) Facing the challenges of $\mathrm{Cu}, \mathrm{Fe}$ and $\mathrm{Zn}$ homeostasis in plants. Nat Chem Biol 5: 333-340.

7. Briat JF, Duc C, Ravet K, Gaymard F (2010) Ferritins and iron storage in plants Biochim Biophys Acta 1800: 806-814.

8. Rodríguez N, Menéndez N, Tornero J, Amils R, de la Fuente V (2005) Internal iron biomineralization in Imperata cylindrica, a perennial grass: chemical composition, speciation and plant localization. New Phytol 165: 781-789.

9. de la Fuente V, Rufo L, Rodríguez N, Amils R, Zuluaga J (2010) Metal accumulation screening of the Río Tinto flora (Huelva, Spain). Biol Trace Elem Res 134: 318-341.

10. Amils R, de la Fuente V, Rodríguez N, Zuluaga J, Menéndez N, et al. (2007) Composition, speciation and distribution of iron minerals in Imperata cylindrica. Plant Physiol Biochem 45: 335-340.

11. de la Fuente V, Rodríguez N, Amils R (2012) Immunocytochemical analysis of the subcellular distribution of ferritin in Imperata cylindrica (L.) Raeuschel, an iron hyperaccumulator plant. Acta Histochem 114: 232-236.

12. Theil EC (1987) Ferritin: structure, gene regulation, and cellular function in animals, plants, and microorganisms. Annu Rev Biochem 56: 289-315. 
Citation: Franco A, Rufo L, Fuente Vdl (2015) Fe Absorption and Distribution of Imperata cylindrica (L.) P. Beauv. under Controlled Conditions. J Environ Anal Toxicol 5: 335. doi:10.4172/2161-0525.1000335

Page 7 of 7

13. Wade VJ, Treffry A, Laulhère JP, Bauminger ER, Cleton MI, et al. (1993) Structure and composition of ferritin cores from pea seed (Pisum sativum). Biochim Biophys Acta 1161: 91-96.

14. Cowley JM, Janney DE, Gerkin RC, Buseck PR (2000) The structure of ferritin cores determined by electron nanodiffraction. J Struct Biol 131: 210-216.

15. Gálvez N, Fernández B, Sánchez P, Cuesta R, Ceolín M, et al. (2008) Comparative structural and chemical studies of ferritin cores with gradual removal of their iron contents. J Am Chem Soc 130: 8062-8068.

16. Zuluaga J, Rodríguez N, Rivas-Ramirez I, de la Fuente V, Rufo L, et al. (2011) An improved semiquantitative method for elemental analysis of plants using inductive coupled plasma mass spectrometry. Biol Trace Elem Res 144: 13021317.

17. Berazaín R, de la Fuente V, Sánchez-Mata D, Rufo L, Rodríguez N, et al. (2007) Nickel localization on tissues of hyperaccumulator species of phyllanthus $\mathrm{L}$. (Euphorbiaceae) from ultramafic areas of Cuba. Biol Trace Elem Res 115: 6786.

18. Bermúdez V, Serrano MD, Tornero JD, Dieguez E (1999) Er incorporation into congruent LiNbO3 crystals. Solid State Communications 112: 699-703.

19. Franco A, Rufo L, Rodríguez N, Amils R, Fuente V (2013) Iron absorption, localization, and biomineralization of Cynodon dactylon, a perennial grass from the Río Tinto basin (SW Iberian Peninsula). J Plant Nutr Soil Sci 176: 836-842.

20. Reeves RR, Baker AJM (2000) Metal-accumulating plants. In: Raskin I, Ensley BD (eds.) Phytoremediation of Toxic Metals. Wiley, New York, pp 193-229.

21. Kabata-Pendias A (2001) Trace Elements in Soils and Plants ( $3^{\text {rd }}$ edn) CRC, Boca Raton, FL, pp 413.

22. Ye Z, Baker AJM, Wong MH, Willis AJ (1998) Zinc, lead and cadmium accumulation and tolerance in Typha latifolia as affected by iron plaque on the root surface. Aquat Bot 61: 55-67.

23. Chabbi $A$ (1999) Juncus bulbosus as a pioneer species in acidic lignite mining lakes: interactions, mechanism and survival strategies. New Phytol 144: 133142

24. Vesk PA, Nockolds CE, Allaway WG (1999) Metal localization in water hyacinth roots from an urban wetland. Plant Cell Environ 22: 149-158.

25. Xiaomei L, Qitang W, Banks MK, Ebbs SD (2005) Phytoextraction of Zn and Cu from sewage sludge and impact on agronomic characteristics. J Environ Sci Health A Tox Hazard Subst Environ Eng 40: 823-838.

26. Du J, Yan C, Li Z (2013) Formation of iron plaque on mangrove Kandalar. Obovata (S.L.) root surfaces and its role in cadmium uptake and translocation. Mar Pollut Bull 74: 105-109.

27. Fürtig K, Pavelic D, Brunold C, Brändle R (1999) Copper- and Iron-induced injuries in roots and rhizomes of reed (Phragmites australis). Limnologica 29:
60-63.

28. Taggart MA, Mateo R, Charnock JM, Bahrami F, Green AJ, et al. (2009) Arsenic rich iron plaque on macrophyte roots--an ecotoxicological risk? Environ Pollut 157: 946-954.

29. Brooks RR (1998) Plants that hyperaccumulate heavy metals: their role in phytoremediation, microbiology, archaeology, mineral exploration and phytomining. Cab International, Wallingford, New York.

30. Bacha RE, Hossner LR (1977) Characteristics of coatings formed on rice roots as affected by iron and manganese additions. Soil Sci Soc Am J 41: 931-935.

31. St-Cyr L, Fortin D, Campbell PGC (1993) Microscopic observations of the iron plaque of a submerged aquatic plant (Vallisneria Americana Minchx). Aquat Bot 46: 155-167.

32. Snowden RED, Wheeler BD (1995) Chemical changes in selected wetland plant species with increasing $\mathrm{Fe}$ supply, with specific reference to root precipitates and Fe tolerance. New Phytol 131: 503-520

33. Chen XP, Kong WD, He JZ, Liu WJ, Smith SE, et al. (2008) Do water regimes affect iron-plaque formation and microbial communities in the rhizosphere of paddy rice. J Plant Nutr Soil Sci 171: 193-199.

34. Hu ZY, Zhu YG, Li M, Zhang LG, Cao ZH, et al. (2007) Sulfur (S)-induced enhancement of iron plaque formation in the rhizosphere reduces arsenic accumulation in rice (Oryza sativa L.) seedlings. Environ Pollut 147: 387-393.

35. Rufo L, Franco A, de la Fuente V (2014) Silicon in Imperata cylindrica (L.) P. Beauv: content, distribution, and ultrastructure. Protoplasma 251: 921-930.

36. Rajesh R, Shrivastva BK (2014) Numerical simulation of vegetated mine dump slope with reference to small plants. Int J Min Sci Technol 24: 111-115.

37. Paz-Alberto AM, Sigua GC, Baui BG, Prudente JA (2007) Phytoextraction of lead-contaminated soil using vetivergrass (Vetiveria zizanioides L.), cogongrass (Imperata cylindrica L.) and carabaograss (Paspalum conjugatum L.). Env Sci Pollut Res 14: 498-504.

38. Ashraf MA, Maah MJ, Yusoff I (2011) Heavy metals accumulation in plants growing in ex tin mining catchment. Int J Environ Sci Tech 8: 401-416.

39. Abidemi OO (2013) Accumulation and contamination of heavy metals in soil and vegetation from industrial area of Ikirun, Osun state, Nigeria. Glob J Pure Appl Chem Res 1: 25-34.

40. Yan WD, Xiang JL, Tian DL (2006) Study on characteristics of soil in mining abandoned lands in Xiangtan, Hunan Province. Scientia Silvae Sinicae 42: 12 18.

41. Li MS, Luo YP, Su ZY (2007) Heavy metal concentrations in soils and plan accumulation in a restored manganese mineland in Guangxi, South China. Environ Pollut 147: 168-175. 